DOI:

UDC 621.18:622

S.K. Meshchaninov, Doctor of Technical Sciences, Professor, sergey.meshaninov@mail.ru

R.V. Voloshin, magister

D.S. Krivencov, magister, STRANNIK1997@mail.ru

Dnieper State Technical University, Kamianske

\title{
MATHEMATICAL MODELING OF CONTINUOUS METAL BEHAVIOR WITH DEFECTS OF MACROSTRUCTURE IN THE ROLLING PROCESS
}

The mathematical model of the process of rolling a continuous cast billet with defects of macrostructure on a smooth barrel and in calibers is presented. The boundary conditions are given by the speed of rotation of the rolls, the restriction of degrees of freedom of the workpiece and the rolls, as well as the coefficient of friction on the contact surface of the rolls-workpiece. For hot rolling, it was considered permissible to consider rolling rolls as a rigid, non-deformable rigid body. For the workpiece material used an elastic-plastic model of environmental behavior. There have been two cases considered: rollerless rolling on a smooth barrel and rolling in rectangular caliber. The roll material is steel, the surface is smooth. On the example of rolling in the first pass of the crimp mill, a comparative analysis of caliber rolling and rolling in calibers was carried out. It is shown that rolling on a smooth barrel has the potential to be used in the case of rolling continuous casting with macrostructure defects. The influence of the basic rolling parameters: absolute compression and temperature on the "healing" of macrostructure defects is made.

Keywords: rolling; defects; continuous casting; mathematical modeling; crimp; caliber

Наведено та створено математичну модель процесу прокатки безперервнолитої заготовки з дефектами макроструктури на гладкій бочиі $і$ в калібрах. Граничні умови задаються швидкості обертання валків, обмеження ступенів свободи заготовки і валків, а також коефіцієнтом тертя на поверхні контакту валок-заготовка. Для гарячої прокатки вважсалося допустимим розглядати прокатні валки як жорстке тверде тіло, що не деформується. Для матеріалу заготовки використана пружно-пластична модель поведінки середовища. Було розглянуто два випадки: бескалибрової прокатка на гладкій бочиі і прокатка в прямокутному калібрі. Матеріал валків - сталь, поверхня гладка. На прикладі прокатки в першому проході обтискової групи стана проведений порівняльний аналіз безкалібрової прокатки і прокатки в калібрах. Доведено що прокатка на гладкій бочиі має потениіал для використання в разі прокатки безперервнолитої заготовки з дефектами макроструктури. Виконана оцінка впливу основних параметрів прокатки: абсолютне обтиснення і температура на «заліковування» дефектів макроструктури.

Ключові слова: прокатка; дефекти; безперевнолита заготовка; математичне моделювання; обтискна кліть; калібр.

\section{Problem's Formulation}

In conditions of constant technological innovation and globalization of markets in front of enterprises, rolled metal manufacturers the problem of increasing production efficiency and ensure competitive products in demand quality. The use of continuous cast billets (CCB) of small cross section revealed a number of problems that did not previously occur with using hot rolled. In the greatest degrees this is typical for cases of production long products from quality structural and spring- 
spring brands steels. Formulation of the problem. CCB defects formed during solidification and may to develop both inside the cast billet and on outer surface.

\section{Analysis of recent research and publications}

In most cases defects have a negative effect on production causing rejection or increase production costs as a result the need to bring blanks in line with the required specifications before they by rolling. Defects expending on the cause can be divided into two groups [1-3]:

- defects specific to a particular streams (found only on one stream due to hardware problems or its settings, for example, due to mold defects, irregularities secondary cooling, improper settings pulling and ruling rolls, etc.); defects specific to a particular swimming trunks (associated with the properties of liquid steel and caused by overheating, the presence of impurities, deoxidation at the stage of out-of-furnace steel processing). In relation to production conditions metal rolling from CCB obtained in conditions:

- high-speed varietal caster with small bending radius, average figures of marriage by type have the form: violations of the geometry of the $\mathrm{CCB}-36.4 \%$;

- macrostructure defects - $17.2 \%$, cracks $31.9 \%$;

- slag inclusions - $4.5 \%$ [2].

On many axial porosity is observed in the templates segregation strips and cracks, developed columnar structure and asymmetry of the ingot zones. In this regard, questions related to the study the behavior of defects in the macrostructure of continuously cast billets (shrink shell, gas bubbles, axial porosity) in the process deformations are relevant following the behavior of these defects in recently widespread mathematical (computer) methods simulation using software complexes like ANSYS, DEFORM, QFORM, PLAST, etc. in which modeling carried out using the finite method elements. Moreover, the variety of processes in each case requires its own approach to modeling techniques.

So in $[3,5]$ presented the results simulation of cutting and screw rolling processes solid blanks in the software package Deform-3D. We studied the effect on the depth of the weight work piece diameter, feed angle, roll calibration crimp mill, as well as the original shape of the ends blanks. In [4], a mathematical simulation of the process of screw firmware blanks large diameter. The aim of the work was to study with using the Deform-3D software package such parameters as a stress-strain state.

In [4], mathematical modeling of the process of screw-piercing large-diameter workpieces was carried out. The aim of the work was to study using the Deform-3D software package such parameters as the stress-strain state metal, the accumulated deformation in terms of the volume of the workpiece, the nature of the development of the deformation, power parameters, firmware time, etc.

Of great interest is the work [5-7] in which mathematical modeling of the process of metal deformation in calibers of various shapes was carried out. During the study, the influence of the stressstrain state on the flow of the deformed metal in various zones of high-quality calibers, depending on their shape, was analyzed. For modeling, the Deform-3D software package was also used. In [6], the problems of calibration design were studied in order to reduce energy consumption and reduce the likelihood of defect formation.

Thus, the aim of the work was to develop a mathematical model and conduct research into the behavior of defects in the macrostructure of continuously cast metal during rolling.

\section{Formulation of the purpose of the study}

For mathematical modeling of the behavior of macrostructure defects during rolling, a computer simulation software package using the Deform-3D finite element method was used.

The rolling process is quite complicated for modeling since it combines the rotational movement of the rolls and the translational motion of the workpiece. To obtain correct results, it is necessary to accurately position the workpiece relative to the rolling rolls and take into account the 
friction conditions at the contact [8-10]. It is also necessary to ensure the capture of the workpiece rolls. As the boundary conditions are set the speed of rotation of the rolls, restrictions on the degrees of freedom of the workpiece and rolls, as well as the coefficient of friction on the contact surface of the roll-workpiece. For hot rolling it is permissible to consider the rolling rolls as a rigid undeformable solid. An elastic-plastic model of the medium's behavior is used for the workpiece material. Two cases were considered: caliber-free rolling on a smooth barrel and rolling in a rectangular caliber. The material of the rolls is steel, the surface is smooth. The diameter of the rolls in both cases was 600 $\mathrm{mm}$. A non-cast cast billet with a section of $150 \times 150 \mathrm{~mm}$ was chosen as the initial billet, the length of the billet was $500 \mathrm{~mm}$ in order to exclude the influence of external zones. Central porosity was modeled through a hole with a diameter of 4,6 and $8 \mathrm{~mm}$.

The appearance of the model after import into the Deform-3D software package and positioning of the workpiece relative to the rolls is shown in Fig. 1. The geometric model of the workpiece was divided into 70,000 tetrahedral finite elements. An elastic-plastic model was chosen as a model of the behavior of the CCB material. Steel 45 was chosen as the material.

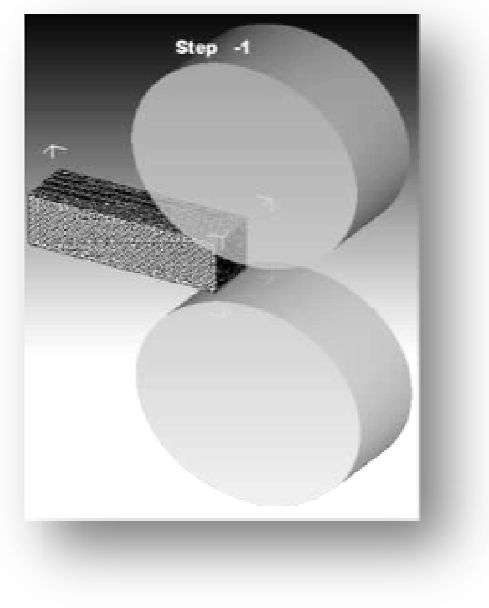

a)

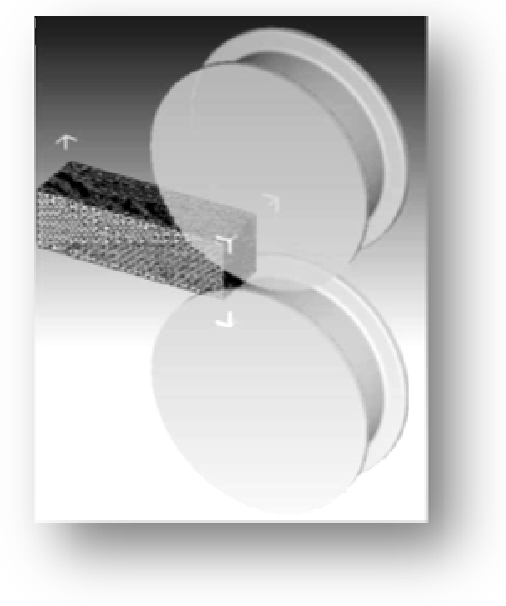

b)

Fig. 1. Geometric rolling model: a — in smooth rolls; $\mathrm{b}$ - rectangular gauge

The rolling temperature of the billet was assumed equal over the entire cross section of the billet and amounted to 1000,1100 and $1200^{\circ} \mathrm{C}$. Temperature changes from contact with the rolls and the deformation process were not taken into account. As conditions on the contact, the friction coefficient was set equal to 0.4 . Rolling speed $-0.1 \mathrm{~m} / \mathrm{s}$. The absolute compression ratio is 30,40 and $50 \mathrm{~mm}$. To ensure the capture of the workpiece by the rolls, a short-term pushing force was applied to the end face of the workpiece [8].

\section{Presenting main material}

The following parameters were selected as output parameters for the analysis of the rolling of an overburden with defects in the macrostructure in smooth rolls: absolute height strain hi, strain rate $i$, stress intensity i, and the degree of accumulated strain . Reading these parameters from the computer model was carried out for 4 points located along the height of the workpiece: P1 is the crimped face of the workpiece, $\mathrm{P} 2$ is $\mathrm{j}$ the height of the workpiece, P3 is the beginning of the axial porosity zone; $\mathrm{P} 4$ - axis of the workpiece. Evaluation of the effectiveness of the axial porosity rolling process was evaluated in terms of minimizing its size and creating a favorable stress-strain state [11]. 
Consider a comparative analysis of the rolling process in gauges and on a smooth barrel for the following combination of factors: rolling temperature $\mathrm{T}_{\Pi}=1200^{\circ} \mathrm{C}$, absolute reduction $\mathrm{h}=30 \mathrm{~mm}$. A comparative analysis of the nature of the penetration of deformation into the axial zone of the workpiece is shown in Fig. 2.

The calculation data indicate that the penetration of high-altitude deformation into the axial zone of the workpiece, and, consequently, the reduction in axial porosity, is greater in the case of rolling on a smooth barrel: $1.6 \mathrm{~mm}$ versus $0.6 \mathrm{~mm}$. A similar effect was observed when the rolling temperature was set at 1000 and $1100^{\circ} \mathrm{C}$. This allows us to conclude that the preferred use of rolling on a smooth barrel in the first passes of the crimp group of the rolling mill.

The distribution of stress intensity is shown in Fig. 3. From the above data, we can conclude that the level of stresses arising when rolling on a smooth barrel is $1.1 \ldots 1.3$ times less than when rolling in calibers.

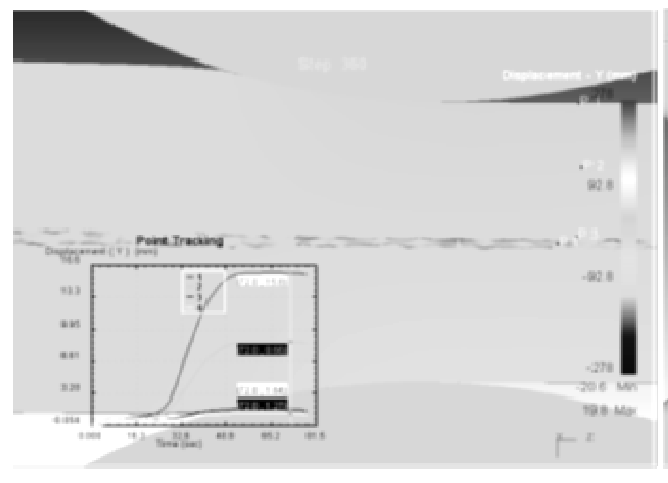

a)

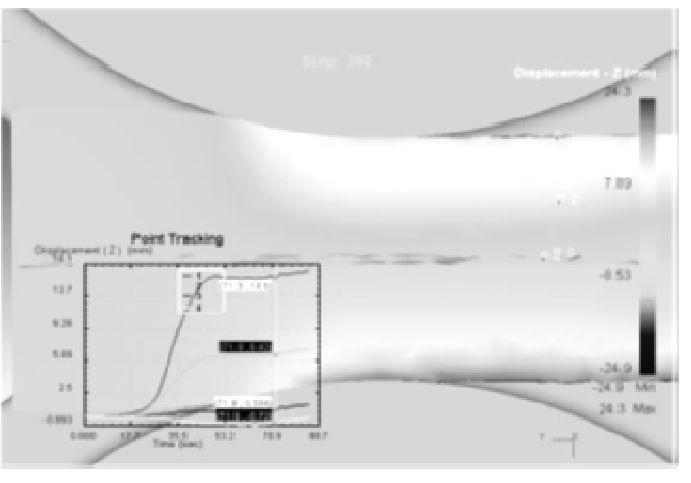

b)

Fig. 2. Distribution of absolute deformation along the height of the roll $\left(\mathrm{Tp}=1200^{\circ} \mathrm{C}, \mathrm{h}=30\right.$ $\mathrm{mm}$ ) during rolling: $\mathrm{a}$ — on a smooth barrel; $\mathrm{b}$ — in a rectangular caliber

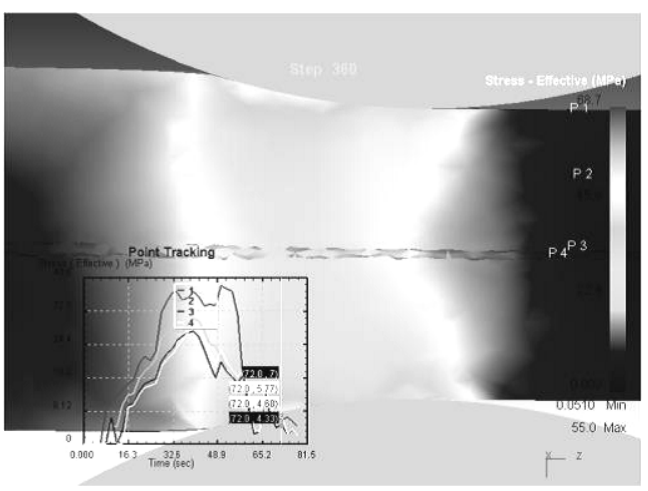

a)

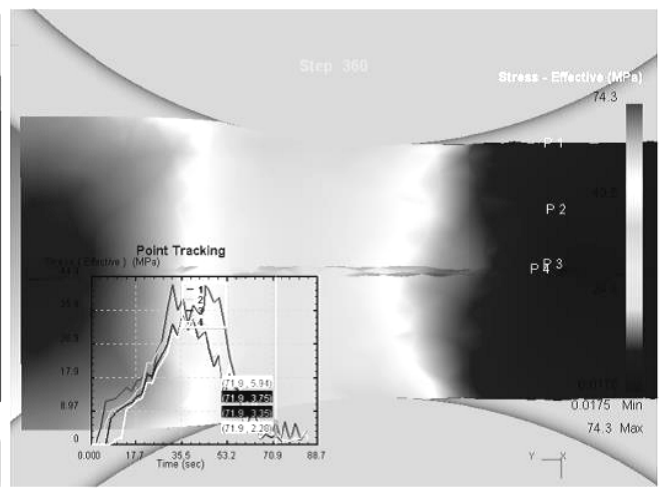

b)

Fig. 3. Distribution of stress intensity along the height of the roll $\left(\mathrm{Tp}=1200^{\circ} \mathrm{C}, \mathrm{h}=30 \mathrm{~mm}\right)$ during rolling: $\mathrm{a}$ - on a smooth barrel; $\mathrm{b}$ - in a rectangular caliber

Thus, as a result of preliminary calculations, we can make an assumption about the potential of non-caliber rolling in the case of using blanks with macro-structure defects, since such rolling is characterized by greater penetration of altitudinal deformation into the axial zone of the ingot and a more favorable stress-strain state [11]. Based on the foregoing, for the initial study of the behavior of macrostructure defects during rolling, the case of rolling on a smooth barrel was chosen. The 
calculation results are shown in Fig. 4. As a result of the analysis of the obtained dependences, we can conclude that from the point of view of the maximum reduction in the axial porosity, the rolling temperature of $1000^{\circ} \mathrm{C}$ and the absolute reduction of $50 \mathrm{~mm}$ will be most favorable. In this case, the axial porosity is reduced to a minimum and will be eliminated during subsequent passes. At the same time, as, for example, with an absolute reduction of $30 \mathrm{~mm}$, the most favorable rolling temperature is $1200^{\circ} \mathrm{C}$. Thus, the most rational combination of these factors can be discussed in the case of an additional analysis of equipment capabilities and economic factors [11]. An analysis of the influence of rolling factors on the stress state indicates that the rolling temperature has a greater influence on the magnitude of the stresses, while the effect of absolute reduction is less. In any case, a lower stress level is observed when the rolling temperature is exceeded to $1200^{\circ} \mathrm{C}$ and the absolute reduction is reduced to $30 \mathrm{~mm}$. A similar picture is also observed in the dependences of the accumulated degree of deformation, however, here the influence of temperature is less than the effect of absolute compression.

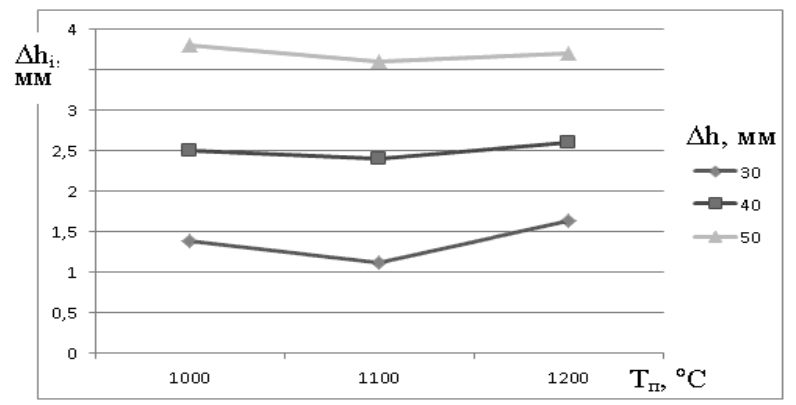

a)

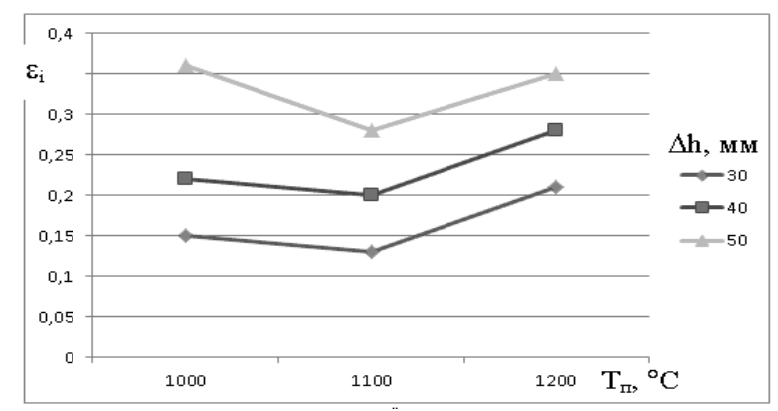

b)

Fig. 4. Dependence on the magnitude of the absolute compression and rolling temperature: $\mathrm{a}$ - penetration of high-altitude deformation; $\mathrm{b}$ - strain intensity; [11].

\section{Conclusions}

A mathematical model of the rolling process of $\mathrm{CCB}$ with defects in the macrostructure on a smooth barrel and in gauges is developed. On the example of rolling in the first pass of the crimp group of the mill, a comparative analysis of non-caliber rolling and rolling in calibers is performed. It is shown that rolling on a smooth barrel has the potential to be used in the case of rolling of an overburden with defects in the macrostructure. The influence of the basic rolling parameters was evaluated: absolute compression and temperature on the "healing" of macrostructure defects.

\section{References}

[1] Botnikov, S. A. (2011). Sovremennyj atlas defektov nepreryvnolitoj zagotovki i prichiny vozniknovenija proryvov kristallizujushhejsja korochki metalla. Volgograd. (in russion)

[2] Bykov, P.O. Nikitin, G. M., Serzhanov, R.I. (2007). Kachestvo nepreryvnolityh zagotovok. Trudy Mezhdunarodnoj nauchno-prakticheskoi konferencii «Aktual'nye problemy gornometallurgicheskogo kompleksa Kazahstana».(pp. 379-383). [in Karaganda].

[3] Ju, V., Bodrov, D.V., Ovchinnikov, B.I., Ust'jancev, A.A., Bogatov, A.V. (2009). Issledovanie nestacionarnoj stadii vintovoj prokatki nepreryvnolityh zagotovok na trehvalkovom obzhimnom stane. Trudy XVII mezhdunarodnoj nauchno-tehnicheskoj konferencii «TRUBY - 2009». (pp. 287-288). [in Russion]. 
[4] Romanenko, V.P., \& Sizov, D.V. (2011). Modelirovanie processa vintovoj proshivki zagotovok bol'shogo diametra v dvuhvalkovom stane metodom konechnyh jelementov. Izvestija vysshih uchebnyh zavedenij. Chernaja metallurgija. 36-40. [in Russion].

[5] Kadykov, V.N., \& Umanskij, A.A., \& Mart'janov, Ju.A.. (2011). Modelirovanie processov formoizmenenija defektov pri prokatke $\mathrm{v}$ kalibrah. Metallurgija: Tehnologii, upravlenie, innovacii, kachestvo. Sbornik trudov vserossijskoj nauchno-prakticheskoj konferencii. 146-151. [in Novokuzneck, Russion].

[6] Kinzin, R.I., \& Rychkov, S.S.. (2011) Ispol'zovanie programmnogo kompleksa DEFORM-3D pri modelirovanii processov sortovoj prokatki. Vestnik MGTU im. Nosova. 45-48. [in Russion].

[7] Skljar, V.A. \& Smirnov, E.N.. (2016). Konechno-raznostnye metody v obrabotke metallov davleniem. [Konspekt lekcij dlja studentov special'nosti]. Staryj Oskol [in Russion].

[8] Shljapugin, A.D.. (2010) Modelirovanie i optimizacija tehnologicheskih processov OMD. Samara. [in Russion].

[9] Minayev, A.A., Smirnov, A.N., Grigoriev, M.V.. (2002). Experimental investigation dynamics of condensation of axial zone continuous casting blooms and billets on physical models. 11-th International Metallurgical \& Materials Conference "METAL - 2002”. (pp. 218-226). Hradec nad Moravicні Czech Republic. - Ostrava: VSB - Technical University.

[10] Tripathy, P.K., \& Das, S. (2006). Migration of slab defects during hot rolling. Iron making and Steelmaking. 447-483 [in Russion].

[11] Tirosh, J., \& Shrizby, A., \& Rubinski, I.. (1999). Evolution of anisotropy in the compliances of porous materials during plastic stretching or rolling - analysis and experiments. Mechanics of Materials. 449-460 [in Russion].

\section{МАТЕМАТИЧНЕ МОДЕЛЮВАННЯ ПОВЕДІНКИ БЕЗПЕРЕРВНОЛИТОГО МЕТАЛУ С ДЕФЕКТАМИ МАКРОСТРУКТУРИ В ПРОЦЕСІ ПРОКАТКИ Мсщанінов С.К., Волошин Р.В., Кривенцов Д.С.}

\section{Реферат}

Наведено та створено математичну модель процесу прокатки безперервнолитої заготовки з дефектами макроструктури на гладкій бочці і в калібрах. Граничні умови задаються швидкості обертання валків, обмеженням ступенів свободи заготовки і валків, а також коефіцієнтом тертя на поверхні контакту (валок-заготовка). Для гарячої прокатки вважалося допустимим розглядати прокатні валки як жорстке тверде тіло, що не деформується. Для матеріалу заготовки використано пружно-пластична модель поведінки середовища.

Було розглянуто два випадки: бескалибрової прокатки на гладкій бочці і прокатки в прямокутному калібру. Матеріал валків - сталь, поверхня гладка. Діаметр валків в обох випадках становив 600 мм. В якості вихідної заготовки було обрано безперервнолиту заготовку перетином $150 \times 150$ мм, довжина заготовки становить 500 мм, для того щоб виключити вплив зовнішніх зон. Центральна пористість моделювалася наскрізним отвором діаметром 4 мм, 6 мм і 8 мм. Зміна температури від контакту 3 валками і процесу деформації не враховувалися. В якості умов на контакті задавався коефіцієнт тертя рівний 0,4 . Швидкість прокатки $-0,1 \mathrm{~m} / \mathrm{c}$. Величина абсолютного обтиску - 30 мм, 40 мм і 50 мм. На прикладі прокатки в першому проході обтискової групи стана проведено порівняльний аналіз безкалібрової прокатки i прокатки в калібрах.

Доведено що прокатка на гладкій бочці має потенціал для використання в разі прокатки безперервнолитої заготовки 3 дефектами макроструктури. Виконано оцінку впливу основних параметрів прокатки: абсолютне обтиснення і температура на «заліковування» дефектів макроструктури. Розглядалося два випадки: бескалибровой прокатка на гладкій бочці i 
прокатка в прямокутному калібрі. Матеріал валків - сталь, поверхня гладка. Діаметр валків в обох випадках становив 600 мм.

В результаті проведених досліджень було розроблено математичну модель процесу прокатки НЛЗ з дефектами макроструктури на гладкій бочці і в калібрах. На прикладі прокатки в першому проході обжимної групи сталі проведений порівняльний аналіз бескалибровой прокатки і прокатки в калібрах.

Показано що прокатка на гладкій бочці має потенціал для використання в разі прокатки НЛ3 з дефектами макроструктури. Зроблено оцінку впливу основних параметрів прокатки: абсолютне обтиснення і температура на «заліковування» дефектів макроструктури.

\section{Література}

1. Ботников С. А. Современный атлас дефектов непрерывнолитой заготовки и причины возникновения прорывов кристаллизующейся корочки металла.: Волгоград, 2011. 97 с.

2. Качество непрерывнолитых заготовок. Труды Международной научно-практическои конференции «Актуальные проблемы горно-металлургического комплекса Казахстана», г. Караганда ,8-7 декабря,2007г. / П. О. Быков, Г. М. Никитин, Р. И. Сержанов. 2007. 379 с.

3. Исследование нестационарной стадии винтовой прокатки непрерывнолитых заготовок на трехвалковом обжимном стане. Труды XVII международной научно технической конференции «ТРУБЫ - 2009».2009г. / Ю. В. Бодров, Д. В. Овчинников, В. Л. Устьянцев, А. А. Богатов. 2009. 287 с.

4. Моделирование процесса винтовой прошивки заготовок большого диаметра в двухвалковом стане методом: Известия высших учебных заведений. Черная металлургия конечных элементов / В. П. Романенко, Д. В. Сизов., 2011. 36 с.

5. Моделирование процессов формоизменения дефектов при прокатке в калибрах. Металлургия: Технологии, управление, инновации, качество. Сборник трудов всероссийской научно практической конференции.г. Новокузнецк, 2011г. / В. Н. Кадыков, А. А. Уманский, Ю. А. Мартьянов. 2011. 45 с.

6. Использование программного комплекса DEFORM-3D при моделировании процессов сортовой прокатки: Вестник МГТУ им. Носова. / Р. И. Кинзин, С. С. Рычков. 2011. 45 с.

7. Скляр В. А., Смирнов Е. Н. Конечно-разностные методы в обработке металлов давлением. Конспект лекций для студентов специальности.: Старый Оскол, 2016. 68 с.

8. Шляпугин А. Д. Моделирование и оптимизация технологических процессов ОМД: Самара, 2010. $46 \mathrm{c}$.

9. Экспериментальное исследование динамики сгущения осевых зон непрерывного литья заготовок на физических моделях. 11-я Международная конференция по металлургии и материалам, "METAL - 2002", Hradec nad Moravicнi Czech Republic. - Ostrava: VSB Technical University; А.А. Минаев., А.Н. Смирнов., М.В. Смирнов. 2002. 218 с.

10. Tripathy P.K., Das S. Migration of slab defects during hot rolling. Iron making and Steelmaking. 2006. № 4. C. 447-483.

11. Tirosh J., Shrizby A., Rubinski I.. Evolution of anisotropy in the compliances of porous materials during plastic stretching or rolling - analysis and experiments. Mechanics of Materials. 1999. №7. C. 449-460. 